\title{
Challenges in the implementation of conservation policies in the Reventazón Model Forest, Costa Rica
}

\author{
by José Alberto Cubero Moya ${ }^{1}$, Ligia Quirós ${ }^{2}$ and Mildred Jiménez ${ }^{3}$
}

\begin{abstract}
We present an analysis of the implementation of the main conservation policies in the Reventazón Model Forest in Costa Rica, and its contribution to the sustainability of environmental services. The existing environmental legislation has helped to curtail environmental degradation and loss of forest cover. The Reventazón Model Forest is an initiative created as a means of implementing Costa Rica's commitment to the application of the ecosystem approach, and has served as a framework for putting into practice sustainable development policies with broad participation by communities in Cartago Province. The Payment for Environmental Services (PES) program has played a role in forest conservation and reforestation in $9 \%$ of the Model Forest. The challenge now is to increase the impact of this program in the Reventazón Model Forest, above all in the biological corridors, and we analyze some of the causes that could be limiting the PES program.
\end{abstract}

Key words: environmental services, Model Forest, biological corridor, ecosystem approach

\section{RÉSUMÉ}

Nous présentons une analyse de la mise en œuvre des principales politiques de conservation dans la Forêt Modèle de Reventazón, au Costa Rica, et de la contribution de cette mise en œuvre à la durabilité des services environnementaux. Les lois actuelles sur lenvironnement ont contribué à freiner la dégradation environnementale et la perte de couverture forestière. La Forêt Modèle de Reventazón est une initiative qui a été créée dans le but de mettre en application l’engagement du Costa Rica envers une approche axée sur l'écosystème. Elle sert de cadre à la mise en pratique des politiques sur le développement durable et elle suscite une grande participation de la part des collectivités de la province de Cartago. Le programme Paiements pour des services environnementaux (PSE) a joué un rôle dans la conservation et le reboisement de $9 \%$ de la Forêt Modèle. Le défi consiste maintenant à accroitre l'impact de ce programme sur la Forêt Modèle de Reventazón, mais surtout dans les couloirs biologiques. Nous examinons également certaines causes qui pourraient limiter le programme PSE.

Mots-clés: services de l’environnement, Forêt Modèle, corridor biologique, approche écosystémique

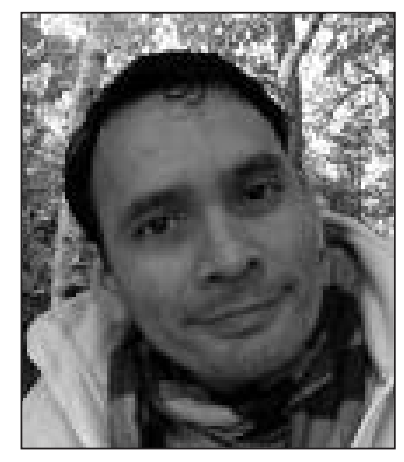

José Alberto Cubero Moya

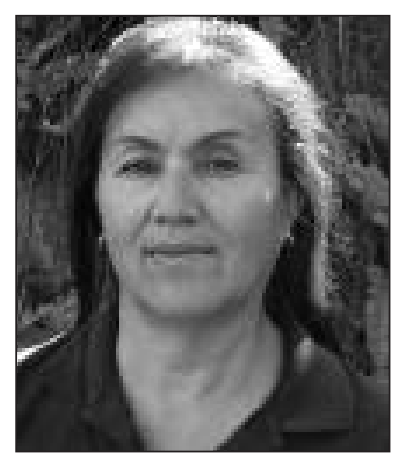

Ligia Quirós

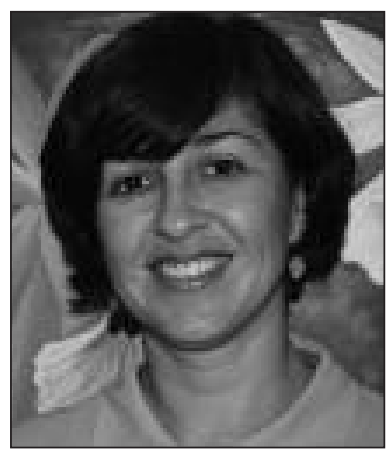

Mildred Jiménez

\footnotetext{
${ }_{1}^{1}$ Fondo Nacional de Financiamiento Forestal FONAFIFO, sobre avenida 7, entre calles 3 y 5, San José, Costa Rica, apartado postal 594-2120. E-mail: jcuberomoya@gmail.com

${ }^{2}$ Sistema Nacional de Áreas de Conservación-Área de Conservación Cordillera Volcánica Central SINAC-ACCVC. Apartado 10104-1000 San José, Costa Rica.

${ }^{3}$ Centro Agronómico Tropical de Investigación y Enseñanza CATIE. 2 km carretera a Siquirres, Turrialba 7170. Cartago. Costa Rica.
} 


\section{Introduction}

Costa Rica's efforts to achieve sustainable development have centred, in many cases, on policies promoting the conservation of a variety of ecosystem goods and services. These efforts are extremely important due to the many growing pressures being exerted on forests, biodiversity and natural resources in general. The environmental policies and legislation already in place in Costa Rica constitute part of a process; some of these have been successful in slowing the exploitation of natural resources through a combination of programs and incentives aimed at control and protection, as is the case for the Payment for Environmental Services (PES) Program, the National System of Protected Areas, the National Biological Corridors Program, the Blue Flag Ecological Program, the Agro-Environmental Agenda and, most recently, the National Strategy for Climate Change. In the majority of cases, these policies continue to serve as a framework for action at the higher planning levels of each country, but are difficult to apply at the institutional level (e.g., lack of installed capacity, human and financial resources) and, even more so, are not well known by the target groups who would be the direct beneficiaries as well as those who are called to act locally to turn this global policy approach into reality. Within this context, the networks and connections established under the Model Forest program help to fill these gaps (Quirós and Martinez 2008).

The Reventazón Model Forest, located in the Costa Rican province of Cartago (Fig. 1), is an initiative initially proposed as a means of implementing the ecosystem approach that forms a key element of the Convention on Biological Diversity, to which Costa Rica is a signatory. The development of the Model Forest has not only provided an opportunity to put into practice many of Costa Rica's conservation policies, but has also become a platform for participation by and cooperation among a variety of stakeholders in civil society working towards achieving the principles of the ecosystem approach. It has also been an opportunity to realize the Model Forest principles, focusing on the principle of compromise along with sustainability and conservation. The implementation of many of these policies has been very successful in some cases (e.g., the biological corridors and protected areas that have taken on great relevance for environmental management by municipalities and community organizations) while in others it has been less successful. The PES system, for example, has not had the impact here that it has had in other parts of Costa Rica. Based on these considerations, this paper sets out to analyze the successes and challenges in promoting conservation and sustainable development in the Model Forest.

\section{The Payments for Environmental Services Program in Costa Rica}

In Costa Rica, economic incentives for environmental services provided by forests and forest plantations began in 1996 with the enactment of the Forestry Act [Ley Forestal] No. 7575. This law provided for the creation of the Payments for Environmental Services Program to be administered by the National Forest Financing Fund [Fondo Nacional de Financiamiento Forestal] or FONAFIFO. It identified four distinct environmental services: mitigation of greenhouse gas emissions, protection of water for urban, rural or hydroelectric use, protection of biodiversity for conservation and sustainable use, and protection of natural scenic beauty for tourism and scientific purposes (ALRCR 1996). Several different methods for PES exist, including forest protection, reforestation, natural regeneration, and the establishment of agro- forestry systems, all focussed on priority areas throughout Costa Rica.

Between 1997 and 2007, the program resulted in the protection of 531959 ha of forest, reforestation of 39036 ha, management of 28066 ha of forest ${ }^{4}$, and the planting of 1945552 trees in agro-forestry systems, for a total of 599061.50 ha. The data on forest cover in Costa Rica (University of Alberta - ITCR 2005) shows that $45 \%$ (1 $118995 \mathrm{ha}$ ) of existing forest cover is under some level of protection in protected forest areas with an additional $44 \%$ of forest cover considered to have been conserved through the PES program. This shows the favourable impact of the program on recovery and conservation of Costa Rica's forests.

Nationally, the PES Program administers an annual budget of approximately \$16 million. From 1997 to 2008, approximately US $\$ 180$ million was invested in PES (J.M. Rodriguez ${ }^{5}$, personal communication, 2008). Some 7242 private owners of forests, forestry plantations or agro-forestry systems have participated in the program (FONAFIFO 2008). The majority of these are small and medium owners with an average landholding of 90 ha for farms under the protection method and 30 ha for landholdings under the reforestation method.

Through the PES program, the sale of these services by owners of forests and plantations within the Reventazón Model Forest represents an income for forestry activity of approximately US \$3 031600 between 2003 and 2007. This amount is distributed as follows: US \$25 800 for projects under the agro-forestry system method, US \$2 822500 under the forest protection method, US \$59 200 through protection of forests for water resource purposes, and US \$124 100 for reforestation projects (Cubero 2008).

\section{The National Biological Corridors Program in Costa Rica}

The National Biological Corridors Program was created as a result of the Mesoamerican Biological Corridor Project, and is facilitated by the National System of Conservation Areas of the Ministry of Environment, Energy and Telecommunications (PNCB 2009). The program aims to strengthen the country's biological corridors and to implement the ecosystem approach based on the network of connectivity and the identification of conservation gaps (Quirós and Martinez 2008). The management of biological corridors fosters social cooperation aimed at promoting biodiversity conservation and the sustainable use of natural resources, thereby contributing to improving the quality of life of the inhabitants of the various regions where the corridors are located.

\section{The Protected Forest Areas of Costa Rica}

Costa Rica has a system of protected forest areas that is administered by the National System of Conservation Areas of the Ministry of Environment, Energy and Telecommunications. The objectives of the protected areas are:

- to conserve the natural environments representative of the various bio-geographic regions and the most fragile

4PES methods in effect during the periods 1997-99 and 2001-02 for the exploitation of forest resources.

${ }^{5}$ Executive Director of FONAFIFO, San José, Costa Rica. 


\section{Ibero-American Model Forest Network}

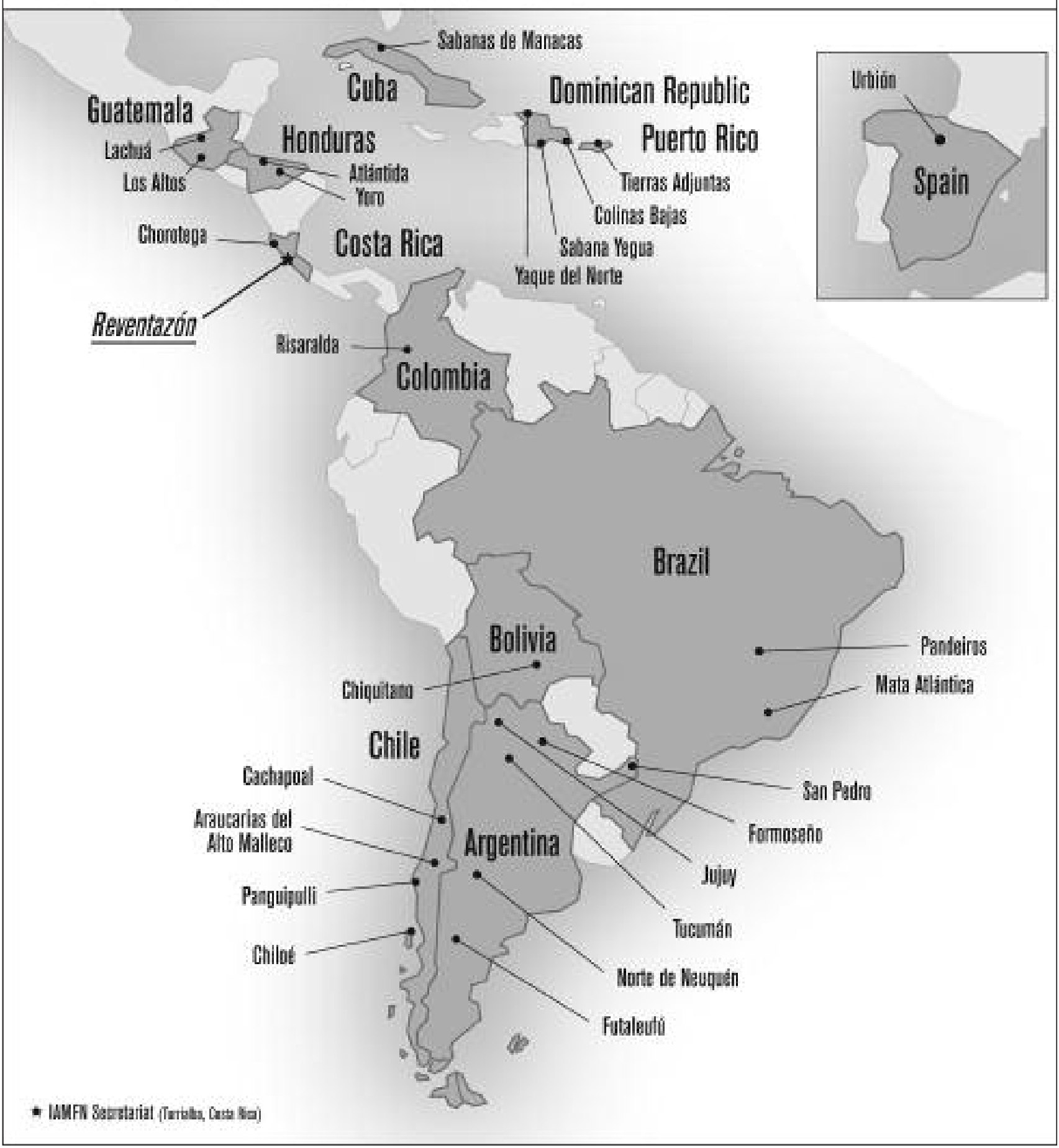

Fig. 1. Location of the Reventazón Model Forest

ecosystems in order to ensure the equilibrium and continuity of evolutionary and ecological processes;

- to safeguard genetic diversity of the forest species on which evolutionary continuity depends, particularly those that are endemic, threatened or in danger of extinction;

- to ensure the sustainable use of ecosystems and their ele- ments by fostering the active participation of neighbouring communities;

- to encourage scientific research, the study of ecosystems and their equilibrium, as well as the knowledge and technologies permitting the conservation and sustainable use of the country's natural resources; 
- to protect and improve the aquifers and watersheds in order to reduce and avoid the negative impacts of their mismanagement; and

- to protect the natural surroundings and beauty of historical and architectural sites, national monuments, archaeological sites and places of historic and artistic importance for the sake of national culture and identity.

Costa Rica is internationally recognized as one of the most attractive tourist destinations and this is due primarily to the beauty of its protected areas. Because of this and because of the need to include the local communities in generating revenues from protected areas, the National System of Conservation Areas has developed strategic alliances with local communities, especially in the areas of influence (buffer zones or "areas de amortiguamiento" are not defined in the legislation). These alliances aim to strengthen the protected area through activities such as tourist services, control and protection, and environmental education, as well as strengthening the community by providing additional revenues to families for offering services in the protected areas such as tourist guiding, administration of parking areas, food services and sale of souvenirs (Quirós and Martinez 2008).

\section{Experience with Implementation of Policies on Con- servation and Sustainable Development Through the Reventazón Model Forest}

The Reventazón Model Forest comprises the whole of the province of Cartago, covering an area of 310000 ha. In 2005, forest cover in the Model Forest was 203695 ha (FONAFIFO 2008), which represents more than $50 \%$ of the territory defined as secondary forest, forest plantations, páramo (tropical highlands) or natural forest. Coffee growing accounts for 7964 ha, non-forest areas (agriculture, sugar cane, pastureland) for $79757 \mathrm{ha}$, and urban use 4679 ha. Protected forest areas cover 141644 ha or $45 \%$ of the Model Forest.

The majority of the forests and natural ecosystems of the Model Forest are within National Parks (Turrialba Volcano, Irazu Volcano, Chirripo, Tapanti-Macizo Cerro de la Muerte, Barbilla and Braulio Carrillo) and occupy $62 \%$ of the surface area of the protected areas. One of Costa Rica's few archaeological sites, the Guayabo National Monument, is also within the Model Forest. The Model Forest is also home to two private Forest Fauna Refuges, the Cerro Las Vueltas Biological Reserve, four Forest Reserves (Los Santos, Río Macho, Cordillera Volcánica Central, and Río Pacuare) that cover $27 \%$ of forest protected areas, and four Protective Zones (Río Navarro-Sombrero, Cuenca del Río Tuis, Cerros de La Carpintera, and Río Tiribí) that make up 9\% of the protected forest areas.

Visits by tourists to many of these protected areas have awakened the interest of the communities that live in the areas of influence. The Model Forest has promoted contacts, technical support and human resources training, and has also supported community groups in developing a form of business model similar to a concession and in obtaining the necessary financing. It currently supports the Guayabo Monument Guides Association (U-SERE) that is dedicated to archaeological and ecological tourism, the indigenous Cabécar communities of Nairi Awari that work with Barbilla National Park in collaboration with the Manitoba Model Forest (Canada), the ASOTUR group of Guides of the Irazú Vol- cano National Park, and the Chamber of Tourism of Santa Cruz-Volcán Turrialba focused mainly on agro-tourism.

Because many of the forests on which the conservation and provision of environmental goods and services depends are outside the protected forest areas, the Model Forest has also focussed on promoting and strengthening two biological corridors as a way of fostering connectivity, community participation and integrated planning with local institutions for issues related to environmental management. The initiatives promoted by the Model Forest are the Central Volcanic Talamanca Biological Corridor (CBVCT), and the Subcuenca Reventado Agua Caliente Biological Corridor (COBRI SURAC), which describes itself as "linking natural and urban ecosystems".

From 2003 to 2007, a total of 64 PES projects were established within the Model Forest with 9005 ha in forest protection, 152 ha in reforestation and 19868 trees in agro-forestry systems. Of these projects, 17 fall within proposed biological corridors within the Model Forest, representing 9\% of the forest cover in the biological corridors. There are also 19 PES projects within the protected forest areas with 2435 ha of protected forest. The majority of these (16 projects) are in Forest Reserves (Reserve Forestal) and the Protective Zone (Zona Protectora). The other three PES projects are under the forest protection method in National Parks. Seven forest protection PES projects are located in Indigenous Territories (3505 ha).

While the PES program has made a significant contribution to conserving forests and strengthening connectivity in the Model Forest, the impact is still relatively small because of the constant pressure to convert forests to other uses that threaten water conservation, biodiversity and other environmental services. Because of this, a priority is now being placed on environmental education as an alternative approach that seeks to avoid the conflicts that arise out of erroneous interpretations of the law, while also raising awareness among the inhabitants about the importance of the services provided by forests in the region.

Despite the efforts that have been made by local agencies, especially the Costa Rican Electricity Institute, to promote reforestation in the Reventazón river basin, there is still an enormous challenge to include reforestation for forest plantations and agro-forestry systems as a strong alternative among the options for local sustainable development. The data show that the PES system administered by FONAFIFO for reforestation and agro-forestry systems has not had a strong impact in the Model Forest in comparison with the total impact in the rest of the country. The reasons why the PES program has not had a stronger impact in this zone need to be considered in connection with the local socio-economic and cultural context, as well as factors inherent in the program that limit its implementation.

Some of the reasons that have been expressed focus on the lack of information about, and promotion of, the program towards landowners, a task in which the Model Forest together with other local stakeholders could play a role. Other limiting factors concern the requirements that FONAFIFO imposes on potential beneficiaries. Among the most difficult requirements for many landowners is the requirement to submit a copy of the management plan and land ownership, as well as the requirement to employ a forest manager who must be paid fees stipulated by law. 
Finally, in order for landowners to complete the entire procedure involved in enrolling in one of the methods of the PES program through FONAFIFO, they must be fully convinced of the benefits of forest protection and reforestation. Consequently, the biggest challenge facing the Model Forest is to contribute, through education and awareness-raising, to a greater understanding of the value of the environmental services provided by trees and forests, and at the same time, to continue encouraging the alliances that will ensure environmental, economic and social sustainability in the areas in which it operates, but especially in the biological corridors, thereby contributing to fulfilling Costa Rica's commitment to sustainability and conservation.

\section{References}

[ALRCR] Legislative Assembly of the Republic of Costa Rica. 1996. Ley forestal [Forest Act] n 7575. 16 April 1996. San José, Costa Rica.

Cubero, J. 2008. El Aporte del Programa de Pago por Servicios Ambientales en Costa Rica y su Importancia en el Bosque Modelo Reventazón en la Conformación de los Corredores Biológicos y Actividades Forestales Productivas [The contribution of the Payments for Environmental Services Program in Costa Rica and its importance in the Reventazón Model Forest in the establishment of biological corridors and productive forest activities]. Presented at the 1st Ibero-American Model Forests Congress, Soria, Spain.

[FONAFIFO] National Forest Financing Fund. 2008. Capas de información digital - proyectos de PSA. Department of Control and Monitoring. San José, Costa Rica.

[PNCB] National Program of Biological Corridors of Costa Rica. 2009. Available from http://www.sinac.go.cr/corredoresbiologicos/ home.html

Quirós, L., and J. Martínez. 2008. Bosque Modelo Reventazón: Plataforma integradora de policías de conservación de biodiversidad en Costa Rica [Reventazón Model Forest: A platform for the integration of biodiversity conservation policy in Costa Rica]. 1st Ibero-American Model Forests Congress, Soria, Spain. 200 p.

University of Alberta - ITCR. 2005. Estudio de monitoreo de la cobertura forestal de Costa Rica 2005. University of Alberta, Edmonton, Canadá, Instituto Tecnológico de Costa Rica and FONAFIFO. San José, Costa Rica. 37 p. 